\title{
An Inhibitor of Sodium Transport in the Urine of Dogs with Normal Renal Function
}

\author{
Herve Favre, Kuo Hwa Hwang, R. William Schmidt, Neal S. Bricker, \\ and JACQUES J. BOURGOIGNIE with the techncial assistance of \\ Pil Seup Yoo and Kwang Hwang \\ From the Section of Kidney and Electrolyte, Division of Nephrology, \\ Department of Medicine, Albert Einstein College of Medicine, \\ Bronx, New York 10461
}

A B S T R A T The urine and serum of chronically uremic patients and dogs contain an inhibitor of sodium transport that reduces short-circuit current (SCC) in the toad bladder and produces natriuresis in the rat. The present studies represent an effort to determine whether the same inhibitor is detectable in urine of normal dogs maintained on a sodium intake varying from 3 to $258 \mathrm{meq} /$ day. Observations were made with and without fludrocortisone. The same Sephadex G-25 gel filtration fraction previously shown to contain the "uremic" inhibitor was tested in both the isolated toad bladder and rat bioassay systems. The fraction from dogs maintained on $258 \mathrm{meq}$ sodium plus $0.2 \mathrm{mg}$ fludrocortisone/day consistently inhibited SCC in the toad bladder and induced a natriuresis in the rat $(P<0.001)$. The fraction from dogs on the same sodium intake without fludrocortisone was also natriuretic $(P<0.01)$ but did not inhibit SCC significantly. In contrast, the fraction from dogs fed 3 meq sodium with fludrocortisone or $91 \mathrm{meq}$ sodium without fludrocortisone had no significant effect in either assay system. Thus, an inhibitor of sodium transport has been found in the urine of nonuremic dogs. Both the degree of natriuresis in the rat and the degree of inhibition of SCC in the toad bladder correlated with the state of sodium balance which ensued in the dog.

This work was presented at the Seventh Annual Meeting of the American Society of Nephrology, Washington, D.C., 25 November 1974.

Dr. Bourgoignie was the recipient of a U.S. Public Health Service Research Career Development Award (no. $7 \mathrm{KO}-4$ HL40977). Dr. Favre was supported by an award from the Schweizerische Akademie der Medizinischen Wissenschaften.

Received for publication 7 April 1975 and in revised form 11 July 1975.

\section{INTRODUCTION}

In recent years, efforts have been made in many laboratories to identify a natriuretic hormone which plays a role in the regulation of external sodium balance. In this search, most investigators have used experimental models subjected to expansion of the extracellular fluid volume. However, while evidence has been established beyond doubt that at least one factor, other than aldosterone and the filtered sodium load, is involved in the regulation of sodium excretion, evidence for the thesis that a natriuretic hormone is secreted in response to volume expansion is by no means definitive. A detailed review of the subject has recently been published (1).

Because of the biologic adaptation in sodium excretion which occurs throughout the evolution of chronic progressive renal disease and which is associated with very high rates of sodium excretion per nephron in advanced renal insufficiency (2), our previous efforts to establish the existence of a natriuretic hormone were oriented about chronically uremic patients and animals. In testing our hypothesis we have recently demonstrated an inhibitor of sodium transport in a low-molecular weight fraction of serum and urine of both patients and dogs with chronic uremia (3-7). The inhibitor was not detectable in the serum and urine of normal subjects or dogs. We interpreted the data as indicating that the presence of the inhibitor related to the adaptive natriuresis per nephron that occurs in uremia and suggested that it did not represent a nonspecific uremic toxin which accumulates in the serum because of failure of excretion. Thus, $(a)$ the inhibitor was not demonstrable in the serum and/or urine from a group of eight patients with far advanced chronic renal insufficiency 
(mean glomerular filtration rate [GFR], $4.3 \mathrm{ml} / \mathrm{min}$ ) and the nephrotic syndrome (5); and (b) although the inhibitor was found in the serum from a group of uremic dogs with a mean fractional sodium excretion $\left(\mathrm{FE}_{\mathrm{Na}_{\mathrm{a}}}\right)$ of $4.4 \%$, no significant inhibitory activity was found in the serum fraction from an equally uremic group of animals in which $\mathrm{FE}_{\mathrm{Na}}$ was maintained at less than $0.5 \%$ (7).

If the inhibitor of sodium transport is an effector element of the control system regulating external sodium balance, its presence should be demonstrable in normal subjects and animals with high rates of sodium excretion. The present studies, therefore, were undertaken to determine whether the same inhibitor of sodium transport could be demonstrated in the urine of dogs with normal renal function by using the same fractionation technique and bioassays as were employed in our studies with urine and serum of patients and dogs with chronic uremia. The results demonstrate that an inhibitor of sodium transport is consistently detectable in the urine of dogs maintained on a high salt intake and given a mineralocorticoid hormone for a period of 4 days. The presence of the inhibitor in the urine correlated with the level of sodium excretion and with the degree of sodium retention.

\section{METHODS}

Experiments were performed on 14 normal adult female mongrel dogs weighing between 14.5 and $22 \mathrm{~kg}$. After a training period of at least 1 wk during which the animals received a diet containing about 90 meq sodium/day, each dog was confined to a metabolic cage for a period of 4 days. During the course of the balance studies, the dogs were fed twice daily, at 10 a.m. and 5 p.m., by orogastric intubation. Each feeding consisted of a semiliquid preparation of $200 \mathrm{~g}$ of a synthetic sodium-deficient diet (ICN Nutritional Biochemicals Div., International Chemical \& Nuclear Corp., Cleveland, Ohio) containing $0.75 \mathrm{meq}$ sodium $/ 100 \mathrm{~g}$ food. To this basic diet 0,44 , or $127 \mathrm{meq}$ sodium chloride per feeding was added with and without the addition to the food of $0.1 \mathrm{mg}$ fludrocortisone ( $9 \alpha$ fluorohydrocortisone, Florinef, E. R. Squibb \& Sons, Princeton, N. J.). A total of five groups of dogs was studied under the following conditions: group $A, 3$ meq sodium plus $0.2 \mathrm{mg}$ fludrocortisone daily; groups $B$ and $C, 91$ meq sodium without fludrocortisone; group D, $258 \mathrm{meq}$ sodium without fludrocortisone; and group E, $258 \mathrm{meq}$ sodium plus $0.2 \mathrm{mg}$ fludrocortisone (Table I). With the exception of group B, all animals received half of their daily food, sodium, and mineralocorticoid (when relevant) before the experiments to be described below were initiated.

24-h urine collections were completed daily in all dogs before the morning feeding and analyzed for sodium content. In the animals of group E, escape from the sodium retaining effect of the mineralocorticoid hormone occurred

1 Abbreviations used in this paper: $\mathrm{FE}_{\mathrm{Na}}$, fractional sodium excretion rate; GFR, glomerular filtration rate; $P D$, potential difference; SCC, short-circuit current; $U_{\mathrm{Na}} V$, absolute sodium excretion rate.
TABLE I

Dietary and Drug Regimens of Experimental Animals

\begin{tabular}{cccc}
\hline $\begin{array}{c}\text { Experimental } \\
\text { group }\end{array}$ & $\begin{array}{c}\text { Number of } \\
\text { dogs }\end{array}$ & $\begin{array}{l}\text { Sodium } \\
\text { intake }\end{array}$ & $\begin{array}{c}\text { Fludro- } \\
\text { cortisone }\end{array}$ \\
\hline & & meq/day & mg/day \\
A & 4 & 3 & 0.2 \\
B & 10 & 91 & - \\
C & 10 & 91 & - \\
D & 7 & 258 & - \\
E & 10 & 258 & 0.2 \\
\hline
\end{tabular}

Clearance studies and collection of urine samples for bioassay were performed after 4 days on the regimens described. Group B animals were studied in the fasting state. All other groups were studied after half of the daily allotment of food and mineralocorticoid hormone had been administered.

on the 2nd day in three dogs, on the 3 rd day in six dogs, and on the 4th day in one dog.

On the morning of the 5th day, the animals were transferred from their metabolic cages and were subjected to clearance studies and collection of urine for purposes of assaying for the inhibitor of sodium transport. These studies were performed with the animals unanesthetized and standing quietly in a supporting sling. A priming dose of $10 \%$ creatinine in a $2.5 \%$ dextrose solution was administered and the same solution was infused at a rate of $4.0 \mathrm{ml} / \mathrm{min}$ intravenously throughout the remainder of the study. Urine was collected through an inlying bladder catheter. After the animals had been fed as indicated above and at the usual time (10 a.m.), five 60 -min clearance periods were obtained. A blood sample was collected at the midpoint of each urine collection period. During these periods, the urine was collected in an iced graduated cylinder. From each urine sample a $10-20-\mathrm{ml}$ aliquot was removed hourly for chemical analyses; the remainder of the urine from all clearance periods was pooled and frozen for subsequent fractionation and assay. The values for creatinine clearance and sodium excretion in the text and tables represent the average of the five individual clearance periods.

The 5-h urine samples from individual dogs were fractionated by a method previously described for the urine of human subjects (5). In brief, the total volume of urine was concentrated by lyophilization (model 5012, Refrigeration for Science, Inc., Island Park, N. Y.) to a volume of $50 \mathrm{ml}$. After centrifugation at $4^{\circ} \mathrm{C}$ for $10 \mathrm{~min}$ at $1,800 \mathrm{~g}$ (PR-J centrifuge, Damon/IEC Div., Damon Corp., Needham Heights, Mass.), two 20-25-ml aliquots of the supernate, each equivalent to approximately $2.5-\mathrm{h}$ sample of original urine, were applied to two identical $2.5 \times 95-\mathrm{cm}$ columns packed with Sephadex G-25 (fine grade, Pharmacia Fine Chemicals, Inc., Piscataway, N. J.). Elution was carried out at $4^{\circ} \mathrm{C}$ by gravity with a solution of 10 $\mathrm{mM}$ ammonium acetate at $\mathrm{pH}$ 6.8. The effluent solution (10 tubes of $12 \mathrm{ml}$ each) which appeared immediately after the salt peak, and which previously has been shown to contain the inhibitor of sodium transport in the urine from patients with chronic uremia, was collected from both columns, pooled, lyophilized to dryness, reconstituted in 2-2.3 $\mathrm{ml}$ of distilled water (depending on the amount of urine used for chemical analyses), and stored at $-80^{\circ} \mathrm{C}$ until the day of assay. Thus, each milliliter of sample was 
equivalent to the amount of urine excreted by the dog in $2 \mathrm{~h}$. All samples were fractionated blindly, without the personnel knowing the origin of the sample being prepared.

The activity of the urine fraction from individual dogs was tested in a toad bladder assay (3) and in a rat assay preparation $(4,5)$. In general, enough material was available for performing both types of assay with each fraction.

Female toads, Bufo marinus, from the Dominican Republic (National Reagents, Bridgeport, Conn.) were employed for the toad bladder assay. The technique has been described previously (3). In brief, one hemibladder was mounted in a conventional Lucite transport chamber, with an exposed surface area of $2 \mathrm{~cm}^{2}$. Both surfaces of the bladder were bathed with $4 \mathrm{ml}$ of an anuran Ringer's solution having the following composition in millimoles: $\mathrm{NaCl}, 113 ; \mathrm{KCl}, 2.5 ; \mathrm{CaCl}_{2}, 1.0 ; \mathrm{NaHCO}_{3}, 2.5$; dextrose, 10. The solution was gassed with compressed air, and the $\mathrm{pH}$ of the aerated solution was $8.0 \pm 0.2$. Short-circuit current (SCC) was measured as an index of net transepithelial sodium transport (8). Short-circuiting was maintained continuously manually except for 15-s intervals every $10 \mathrm{~min}$ when the open circuited potential difference (PD) was measured. After the bladders were mounted, an equilibration period of at least $60 \mathrm{~min}$ was allowed before studies were initiated. No membrane was employed for assay unless the SCC and PD values had been stable for a minimum of $30 \mathrm{~min}$ and unless SCC and PD exceeded $30 \mu \mathrm{A} / 2 \mathrm{~cm}^{2}$ and $20 \mathrm{mV}$, respectively.

Because of the known inhibitory effect of ammonium on the SCC of the isolated toad bladder (9), all samples tested on the toad bladder were pretreated to render them ammonium free. To this effect they were adjusted to $\mathrm{pH}$ 10 , evaporated to dryness under a stream of nitrogen gas at $4^{\circ} \mathrm{C}$ for $3.5 \mathrm{~h}$, and reconstituted to their original volume with distilled water. A $50-\mu 1$ aliquot was then tested for ammonium by the Conway microdiffusion method (10). None of the samples tested on the toad bladder assay contained any detectable amount of ammonium.

For performance of the assay, $500 \mu 1$ of ammonium-free urine fraction, adjusted to a $\mathrm{pH}$ of $8.0 \pm 0.2$ and to sodium and potassium concentrations of 110 and $2.5 \mathrm{meq} / \mathrm{liter}$, respectively, was added to the Ringer's solution bathing the serosal surface of the membrane, and $500 \mu \mathrm{l}$ of anuran Ringer's solution was added to the mucosal bathing solution. SCC and PD then were monitored for $60 \mathrm{~min}$ after which the solutions bathing both sides of the bladder were removed, the bladder was washed with fresh Ringer's solution, and $5 \mathrm{ml}$ Ringer's solution was added to both hemichambers. SCC and PD were recorded for an additional $60 \mathrm{~min}$. There were no differences in $\mathrm{pH}$ and osmolality between the solutions bathing the serosal surface of the membrane (containing the urine fraction) and the Ringer's solution bathing the mucosal surface of the bladder.

The rat assay was performed by using animals with a remnant kidney in a manner identical to that previously described for the assay of natriuretic factor in serum and urine fractions from human subjects $(4,5)$. In brief, the urine fraction was adjusted to a $\mathrm{pH}$ of 7.4 and to sodium and potassium concentrations of 140 and 4 meq/ liter, respectively. The natriuretic activity of each sample was then tested by infusing $1 \mathrm{ml}$ of fraction through a jugular venous catheter over a $10-\mathrm{min}$ period and comparing the average pre- and postinfusion values for GFR, absolute sodium excretion rate $\left(\mathrm{U}_{\mathrm{Na}} \mathrm{V}\right)$, and $\mathrm{FE}_{\mathrm{Na}}$. The preinfusion values represent the average of the two $10-\mathrm{min}$ clearance periods obtained immediately before injection of the fraction. The postinfusion values represent the average of six 10-min clearance periods obtained immediately after completion of the infusion. GFR was measured in the rat by the clearance of $\left[{ }^{14} \mathrm{C}\right]$ inulin. All fractions were adjusted and tested by a single person who had no knowledge of the origin of the sample being assayed.

Radioactive inulin was determined in $25-50-\mu 1$ samples of urine and plasma diluted in $10 \mathrm{ml}$ of Aquasol solution (New England Nuclear, Boston, Mass.). The samples were counted in a Tri-Carb liquid scintillation spectrometer (model 3330, Packard Instrument Co., Inc., Downers Grove, Ill.). Sodium and potassium were measured with a flame photometer (model 143, Instrumentation Laboratory, Inc., Lexington, Mass.), and the $\mathrm{pH}$ of the solutions and fractions during their preparation was measured with a glass electrode with a $\mathrm{pH}$ meter (model PHM 26, London Co., Cleveland, Ohio). Creatinine was measured by the method of Bonsnes and Taussky (11) by using an AutoAnalyzer (model AAII, Technicon Instruments Corp., Tarrytown, N. Y.)

The variation for sets of measurements is expressed as the standard error of the mean. Statistical analyses were performed with Student's $t$ test and by variance analysis using Fisher's least significant difference test (12). Significance in the text is expressed as the $2 \mathrm{P}$ value.

\section{RESULTS}

The data for cumulative sodium balance for the 4-day period of observation are presented in Table II for the individual dogs from each of the five groups. All of the dogs on the 3 meq sodium intake (group A) were in negative sodium balance despite the administration of fludrocortisone. The average for the group was $-51 \pm$

TABLE II

4-Day Cumulative Sodium Balance Data

\begin{tabular}{ccrrrr}
\hline & \multicolumn{5}{c}{ Experimental group } \\
\cline { 2 - 6 } $\begin{array}{c}\text { Dog } \\
\text { no. }\end{array}$ & A & B & C & D & E \\
\hline 1 & & 9 & 31 & & 217 \\
2 & & 182 & 19 & & 313 \\
3 & & 48 & 45 & & 253 \\
4 & & 37 & 38 & & 267 \\
5 & & 35 & 49 & & 256 \\
6 & & 41 & 79 & & 177 \\
7 & & 48 & 19 & & 170 \\
8 & -46 & 75 & 53 & 177 & 158 \\
9 & -37 & 70 & 79 & 192 & 301 \\
10 & -69 & 108 & 66 & 17 & 304 \\
11 & -53 & & & 147 & \\
12 & & & & 160 & \\
13 & & & & 105 & \\
14 & & & & 240 & \\
Mean & -51 & 62.3 & 47.6 & 148.2 & 241.6 \\
\pm SE & 6.8 & 16.2 & 7.8 & 26.9 & 18.4 \\
\hline
\end{tabular}

Sodium balance is expressed in milliequivalents as the difference between oral intake and urinary excretion without adjustment for extrarenal losses. Groups of dogs are defined in Table I. 
TABLE III

GFR and Sodium Excretion in Experimental Dogs

\begin{tabular}{|c|c|c|c|c|c|c|c|c|c|c|c|c|c|c|c|}
\hline \multirow{2}{*}{$\begin{array}{c}\text { Dog } \\
\text { no. }\end{array}$} & \multicolumn{3}{|c|}{ Group A } & \multicolumn{3}{|c|}{ Group B } & \multicolumn{3}{|c|}{ Group C } & \multicolumn{3}{|c|}{ Group D } & \multicolumn{3}{|c|}{ Group E } \\
\hline & GFR & $\mathrm{UNa}_{\mathrm{a}} \mathrm{V}$ & $\mathrm{FE}_{\mathrm{Na}}$ & GFR & $\mathrm{UNa}_{\mathrm{Na}} \mathrm{V}$ & $\mathrm{FE}_{\mathrm{Na}}$ & GFR & $\mathrm{UNaV}_{\mathrm{Na}}$ & $\mathrm{FE}_{\mathrm{Na}}$ & GFR & $\mathrm{UNa}_{\mathrm{Na}} \mathrm{V}$ & $\mathrm{FE}_{\mathrm{Na}}$ & GFR & $\mathrm{UNaV}_{\mathrm{Na}}$ & $F E_{\mathrm{Na}}$ \\
\hline & $m l / \min$ & $\mu e q / \min$ & $\%$ & $m l / \min$ & $\mu e q / \min$ & $\%$ & $m l / \min$ & $\mu e q / \min$ & $\%$ & $\mathrm{ml} / \mathrm{min}$ & $\mu e q / \min$ & $\%$ & $m l / m i n$ & $\mu e q / \min$ & $\%$ \\
\hline 1 & & & & 85.6 & 5.0 & 0.03 & 95.7 & 14.9 & 0.10 & & & & 99.6 & 187.4 & 1.26 \\
\hline 2 & & & & 68.0 & 21.0 & 0.20 & 81.0 & 41.2 & 0.36 & & & & 55.0 & 149 & 1.93 \\
\hline 3 & & & & 69.7 & 2.4 & 0.03 & 110.0 & 46.8 & 0.29 & & & & 80.4 & 128.7 & 1.10 \\
\hline 4 & & & & 62.0 & 7.2 & 0.07 & 69.3 & 10.8 & 0.10 & & & & 76.6 & 16.3 & 1.47 \\
\hline 5 & & & & 65.0 & 1.9 & 0.02 & 78.0 & 35.7 & 0.32 & & & & 85.4 & 261 & 2.03 \\
\hline 6 & & & & 78.0 & 20.9 & 0.20 & 102.0 & 40.3 & 0.27 & & & & 125.0 & 313 & 1.68 \\
\hline 7 & & & & 84.6 & 4.8 & 0.03 & 90.3 & 91.0 & 0.61 & & & & 78.5 & 140 & 1.31 \\
\hline 8 & 70.4 & 2.1 & 0.02 & 76.7 & 9.0 & 0.09 & 84.6 & 9.2 & 0.07 & 81.9 & 163.8 & 1.42 & 103.0 & 123 & 0.66 \\
\hline 9 & 86.6 & 2.5 & 0.02 & 99.0 & 4.8 & 0.04 & 101.0 & 3.7 & 0.03 & 74.0 & 79.4 & 0.81 & 113.0 & 70 & 0.40 \\
\hline 10 & 74.6 & 2.3 & 0.02 & 86.6 & 3.1 & 0.02 & 103.0 & 74.0 & 0.37 & 85.3 & 180 & 1.40 & 127.0 & 214 & 1.17 \\
\hline 11 & 58.9 & 9.2 & 0.04 & & & & & & & 89.9 & 143.1 & 1.13 & & & \\
\hline 12 & & & & & & & & & & 82.0 & 142.5 & 1.70 & & & \\
\hline 13 & & & & & & & & & & 98.0 & 62.5 & 0.39 & & & \\
\hline 14 & & & & & & & & & & 58.2 & 110.2 & 1.81 & & & \\
\hline Mean & 72.4 & 4.0 & 0.02 & 77.5 & 7.9 & 0.07 & 91.5 & 36.8 & 0.25 & 81.3 & 125.9 & 1.23 & 94.4 & 174.9 & 1.30 \\
\hline$\pm \mathrm{SE}$ & \pm 5.7 & \pm 1.7 & \pm 0.01 & \pm 3.7 & \pm 2.2 & \pm 0.02 & \pm 4.1 & \pm 9.1 & \pm 0.05 & \pm 4.8 & \pm 16.4 & \pm 0.18 & \pm 7.3 & \pm 22.6 & \pm 0.16 \\
\hline
\end{tabular}

GFR, $U_{N a V}$, and $F E_{N_{a}}$ were determined after the animals had been fed half of their daily sodium and fludrocortisone allotment, except for the animals of group $B$ which were studied in the fasting state. Values are the average of five 60 -min clearance periods (see Methods). Groups of dogs are defined in Table I.

6.8 meq for the 4-day period. The dogs receiving 91 meq sodium/day (groups $\mathrm{B}$ and $\mathrm{C}$ ) had a cumulative balance of $+62.3 \pm 16.2$ and $+47.6 \pm 7.8$ meq. The group receiving $258 \mathrm{meq}$ sodium/day without fludrocortisone (group D) retained an average of $148 \pm 26.9 \mathrm{meq}$ sodium, a value significantly greater than that observed for groups $\mathrm{A}, \mathrm{B}$, and $\mathrm{C}(P<0.001,<0.005$, and $<0.005$, respectively). The dogs receiving $258 \mathrm{meq}$ of sodium/day plus fludrocortisone (group E) exhibited the greatest degree of sodium retention. The cumulative positive sodium balance averaged $241.6 \pm 18.4$ meq, a value significantly greater than that observed in all other groups, including group $\mathrm{D}(P<0.005$, vs. group $D)$. The body weight in the group $E$ animals increased by a mean of $1.2 \pm 0.3 \mathrm{~kg}$ over the 4 days of study $(P<$ 0.001 ). Body weight in the other groups of animals did not change significantly.

Individual and group data for $\mathrm{GFR}, \mathrm{U}_{\mathrm{Na}} \mathrm{V}$, and $\mathrm{FE}_{\mathrm{Na}}$ determined at the conclusion of the balance studies are presented in Table III. For the different groups, GFR ranged from a mean of $72 \mathrm{ml} / \mathrm{min}$ in group A to $94 \mathrm{ml} /$ $\mathrm{min}$ in group $\mathrm{E}$. $\mathrm{U}_{\mathrm{Na}} \mathrm{V}$ ranged from a mean of $4 \mu \mathrm{eq} / \mathrm{min}$ in group $A$ to $175 \mu \mathrm{eq} / \mathrm{min}$ in group $\mathrm{E}$, and $F E_{\mathrm{N} 2}$ ranged from $0.02 \%$ in group $A$ to $1.30 \%$ in group $E$. In general the values for absolute and fractional sodium excretion correlated with the dietary intake of salt, and groups $\mathrm{D}$ and $\mathrm{E}$ had significantly higher values for both $U_{\mathrm{Na}} \mathrm{V}$ and $\mathrm{FE}_{\mathrm{Na}}$ than did the other three groups $(P<0.001$ for both). The differences in values between groups B and C, both of which received 91 meq of sodium/ day, reflect the fact that the group B dogs were studied in the fasting state whereas the group $C$ animals received half of their daily salt load and food before the clearance measurements were initiated.

A representative experiment depicting the effects of the urine fraction from a group $\mathrm{E}$ dog maintained on 258 meq of sodium plus fludrocortisone on SCC and $\mathrm{PD}$ in the isolated toad bladder is presented in Fig. 1. After a 30-min control period, during which SCC and $\mathrm{PD}$ values remained stable at $72 \mu \mathrm{A} / 2 \mathrm{~cm}^{2}$ and $45 \mathrm{mV}$, respectively, $500 \mu 1$ of the urine fraction was added to the Ringer's solution bathing the serosal surface of the membrane and $500 \mu 1$ of Ringer's solution was added to the mucosal side. After a lag period of approximately $5 \mathrm{~min}, \mathrm{SCC}$ and $\mathrm{PD}$ decreased progressively. $60 \mathrm{~min}$ after addition of the fraction, both $\mathrm{SCC}$ and $\mathrm{PD}$ were $60 \%$ of control values. When the bladder was washed and both surfaces were exposed to fresh Ringer's solu-

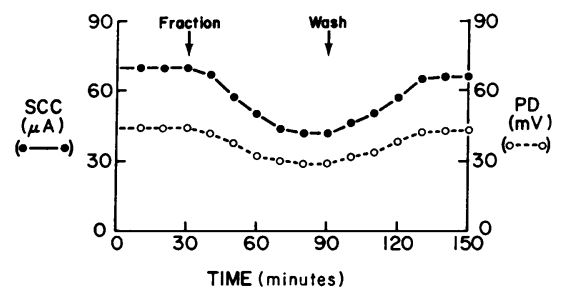

FIGURE 1 Effects of $500 \mu \mathrm{l}$ of urine fraction, equivalent to $1 \mathrm{~h}$ of original urine, on SCC and PD across the isolated toad bladder. The fraction was obtained from a dog maintained on $258 \mathrm{meq}$ sodium plus $0.2 \mathrm{mg}$ fludrocortisone/ day. At $30 \mathrm{~min}$, the urine fraction was added to the Ringer's solution bathing the serosal surface of the bladder. At $90 \mathrm{~min}$, both surfaces of the bladder were washed and exposed to fresh Ringer's solution. 
TABLE IV

Effects of the Urine Fraction on SCC and PD across the Isolated Toad Bladder

\begin{tabular}{|c|c|c|c|c|c|c|c|c|c|c|}
\hline \multirow{2}{*}{$\begin{array}{c}\text { Dog } \\
\text { no. }\end{array}$} & \multicolumn{2}{|c|}{ Group A } & \multicolumn{2}{|c|}{ Group B } & \multicolumn{2}{|c|}{ Group C } & \multicolumn{2}{|c|}{ Group D } & \multicolumn{2}{|c|}{ Group E } \\
\hline & scC & PD & scc & PD & scc & PD & $\mathrm{scc}$ & PD & $\mathrm{scc}$ & PD \\
\hline & \multicolumn{10}{|c|}{ Percent of control } \\
\hline 1 & & & +19 & +18 & -16 & -15 & & & -26 & -19 \\
\hline 2 & & & +4 & +3 & -17 & -17 & & & -29 & -19 \\
\hline 3 & & & -5 & -4 & -22 & -24 & & & -25 & -17 \\
\hline 4 & & & -3 & -3 & -36 & -24 & & & -13 & -10 \\
\hline 5 & & & 0 & 0 & -6 & -4 & & & -43 & -48 \\
\hline 6 & & & 0 & 0 & -23 & -16 & & & -36 & -40 \\
\hline 7 & \multirow{3}{*}{+9} & \multirow{3}{*}{+2} & -5 & -4 & -12 & -10 & & & -40 & -40 \\
\hline 8 & & & +2 & 0 & -30 & -19 & -28 & -25 & -45 & -41 \\
\hline 9 & & & -2 & -2 & +46 & +38 & -18 & -17 & -29 & -25 \\
\hline 10 & 0 & 0 & -4 & -4 & -3 & -2 & -18 & -11 & -45 & -22 \\
\hline 11 & 0 & 0 & & & & & +13 & +6 & & \\
\hline 12 & & & & & & & -40 & -36 & & \\
\hline 13 & & & & & & & -8 & 0 & & \\
\hline \multicolumn{11}{|l|}{14} \\
\hline Mean & +3 & +0.7 & +0.6 & +0.8 & -11.9 & -8.7 & -16.5 & -13.8 & -33.1 & -28.1 \\
\hline$\pm \mathrm{SE}$ & 3 & 0.7 & 2.3 & 2.1 & 6.5 & 5.2 & 7.4 & 6.4 & 3.3 & 4.1 \\
\hline
\end{tabular}

The results represent the percent change obtained $60 \mathrm{~min}$ after addition of the urine fraction from the steady-state control value obtained before adding the urine fraction to the Ringer's solution bathing the serosal side of the membrane. Groups of dogs are defined in Table $I$.

tion, values for both $\mathrm{SCC}$ and $\mathrm{PD}$ returned toward the control levels.

The effects of the urine fraction from the individual dogs on SCC and PD are presented in Table IV. Values obtained 60 min after addition of the test fraction are compared with the control values. None of the urine fractions from the animals in groups $\mathrm{A}$ and $\mathrm{B}$ inhibited SCC by more than $5 \%$ and, for the two sets of group data, the mean changes in SCC were +3 and $+0.6 \%$, respectively. However, a progressive degree of inhibition was apparent with the urine fractions from the animals of groups $\mathrm{C}, \mathrm{D}$, and $\mathrm{E}$. Indeed, in group $\mathrm{E}$ inhibition was observed with every fraction tested and, for this group, the mean fall in SCC was $33.1 \pm 3.3 \%$ $(P<0.001)$. Variance analysis of the results showed that the inhibition of SCC observed in groups C and D was significantly greater than that in groups $A$ and $B$; and the inhibition obtained in group $\mathrm{E}$ was significantly greater than that observed in all other groups.

The data for PD across the toad bladder in the same experiments are also shown in Table IV. The results tend to parallel those for SCC.

No effects on SCC or PD were observed when the urine fraction was added to the Ringer's solution bathing the mucosal surface of the bladder.

Fig. 2 depicts the effects in the rat of two urine fractions obtained from the same dog maintained first on a sodium intake of $3 \mathrm{meq} /$ day and then on $258 \mathrm{meq} /$ day.
On both regimens $0.2 \mathrm{mg} /$ day of fludrocortisone were administered. Values are shown for $U_{\mathrm{Na}} \mathrm{V}, \mathrm{FE}_{\mathrm{Na}}$, and GFR. After infusion of the fraction obtained when the

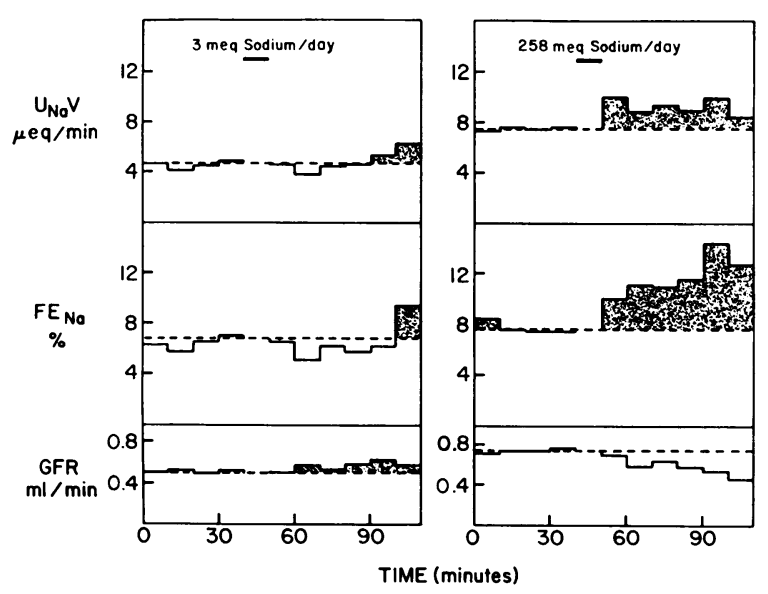

Figure 2 Effects of two urine fractions obtained from the same dog on $\mathrm{U}_{\mathrm{Na}} \mathrm{V}, \mathrm{FE}_{\mathrm{Na}}$, and GFR in the rat. The dog was maintained first on a 3 meq sodium intake (left panel) and then on a $258 \mathrm{meq}$ sodium intake (right panel). On both regimens, $0.2 \mathrm{mg}$ fludrocortisone/day was administered. The broken line represents the mean base-line control values observed before infusion of the fraction. The heavy bar indicates a 10-min period during which $1 \mathrm{ml}$ of fraction, equivalent to $2 \mathrm{~h}$ of original urine, was infused intravenously in the assay rat. 
dog was on the low-salt diet plus fludrocortisone, the mean changes in $\mathrm{U}_{\mathrm{Na}} \mathrm{V}, \mathrm{FE}_{\mathrm{Na}}$, and $\mathrm{GFR}$ remained within $10 \%$ of the preinfusion control levels. By contrast, after infusion of the fraction obtained when the same dog was receiving $258 \mathrm{meq}$ sodium and $0.2 \mathrm{mg}$ fludrocortisone/ day, $U_{\mathrm{Na}} \mathrm{V}$ increased from a control value of $7.52 \mu \mathrm{eq} /$ $\min$ to a peak value of $10.30 \mu \mathrm{eq} / \mathrm{min}$, and $F E_{\mathrm{Na}}$ increased from a control value of $7.5 \%$ to a peak value of $14.5 \%$. The mean increment in $\mathrm{U}_{\mathrm{Na}} \mathrm{V}$ and $\mathrm{FE}_{\mathrm{Na}}$ for the six postinfusion periods averaged $1.84 \mu \mathrm{eq} / \mathrm{min}$ and $4.4 \%$, respectively. The increase in sodium excretion rate occurred despite a progressive fall in GFR throughout the period of study.

The results of the individual assays in the rat for all experimental groups are presented in Table V. The change in GFR was small, inconsistent in direction, and not statistically significant for any group; nor were any significant differences observed between the different groups. There were no significant changes in either $U_{N_{a}} V$ or $F E_{N a}$ after injection of the urine fractions in groups A, B, and C. By contrast, the urine fractions from both groups of animals receiving $258 \mathrm{meq}$ sodium/day induced a significant natriuresis in the assay rat. For group $D, U_{\mathrm{Na}_{2}} \mathrm{~V}$ increased by a mean of $1.32 \pm 0.31 \mu \mathrm{eq} / \mathrm{min}(P<0.01)$, and $\mathrm{FE}_{\mathrm{Na}}$ increased by a mean of $1.29 \pm 0.34 \%(P<0.02)$. For group $\mathrm{E}$, the mean increases in $\mathrm{U}_{\mathrm{Na}} \mathrm{V}$ and $\mathrm{FE}_{\mathrm{Na}}$ averaged $1.66 \pm 0.22$ $\mu \mathrm{eq} / \mathrm{min} \quad(P<0.001)$ and $3.56 \pm 0.83 \% \quad(P<0.005)$, respectively. Analysis of variance showed that the changes in $U_{N_{2}} V$ were significantly greater in group $D$ than in groups $A, B$, and $C$. The changes in both $U_{\mathrm{Na}} \mathrm{V}$ and $\mathrm{FE}_{\mathrm{N}}$ in group $\mathrm{E}$ were significantly greater than in all other groups.

\section{DISCUSSION}

The demonstration of an inhibitor of sodium transport with natriuretic activity in the plasma and urine of chronically uremic patients and animals has led to the suggestion that this substance is part of the effector limb of the physiologic control system regulating sodium excretion (3-7). Several lines of evidence $(5,7)$ suggest that the presence of this natriuretic factor in concentrations detectable with the bioassay systems employed correlates with the dictates for and/or concurrent patterns of sodium excretion. However, because of the chemical alterations of uremic serum and urine, the possibility exists that the natriuretic substance is a nonspecific uremic toxin rather than a component part of a biologic control system. It was considered important, therefore, to determine whether the same factor could be demonstrated in a nonuremic model and whether its presence could be correlated with sodium intake or excretion. The present studies were designed to examine this question with normal dogs maintained on a sodium intake ranging from virtually zero to 258 meq per day with and without the administration of a potent mineralocorticoid hormone. Urine samples for bioassay were obtained after the dogs had been on a specified regimen for 4 days, during which time external balance of sodium was quantified. The results of the bioassays were compared both with external sodium balance for the total 4-day interval and with the contemporaneous patterns of sodium excretion on the morning of the 5 th day. The urine fractions were processed in a manner identical to that employed in previous studies of uremic urine and the fraction obtained from gel filtration through Sephadex G-25 was the same at that which has previously been shown to contain the inhibitor of sodium transport.

The bioassays, using the isolated urinary bladder of the toad and the unanesthetized rat, were performed in the same manner employed in previous studies (3-5), and the majority of urine fractions from individual dogs were tested in both assay systems. The results of the assays with the two systems were closely comparable. With both bioassays, the inhibitor was consistently present in the urine fraction of dogs given $258 \mathrm{meq}$ sodium/day who had "escaped" from the salt-retaining effect of exogenous mineralocorticoid hormone (group E). The steroid itself was not responsible for the results, either directly (by affecting the bioassay systems) or indirectly (by inducing the release of an unknown compound in the dog), since the inhibitor of sodium transport was also present in the urine of dogs given $258 \mathrm{meq}$ sodium/day without mineralocorticoid hormone (group D); moreover, with both assays, the inhibitor was not demonstrable in the urine of dogs given exogenous mineralocorticoid hormone without sodium in their diet (group A).

The present studies also establish a relationship between the presence of the inhibitor of sodium transport in the urine and the concurrent patterns of both sodium balance and sodium excretion. Both the inhibition of SCC in the toad bladder and the induction of a natriuretic response in the rat correlated with the degree of positive sodium balance. Fig. 3 depicts the incidence of positive assays, defined by an inhibition of SCC of at least $20 \%$ in the toad bladder or by a mean increase in $\mathrm{U}_{\mathrm{Na}} \mathrm{V}$ and $\mathrm{FE}_{\mathrm{Na}}$ of $1 \mu \mathrm{eq}$ and $1 \%$, respectively, in the rat. With the urine fraction from the animals in negative sodium balance (group A), no assay was positive. The incidence of positive assays remained low, 6 and $25 \%$, respectively, with the urine fraction from the two groups of animals ( $B$ and $C$ ) which received 91 meq sodium/day and which demonstrated only a modest degree of positive sodium balance. By contrast, in the animals retaining an average of $148 \mathrm{meq}$ sodium (group D), $46 \%$ of the assays were positive. Finally, in the 
group of animals with a cumulative positive sodium balance of 242 meq sodium (group E) $83 \%$ of the assays were positive. Fig. 3 also illustrates a direct relationship between the incidence of positive assays and the mean sodium excretion rate present in each group of dogs at the time of urine collection. It is apparent that the higher the sodium excretion rate, the greater the incidence of positive assays.

At first impression, by comparison with human data, it may appear surprising that $20-\mathrm{kg}$ dogs which received 91 meq sodium/day did not show urinary natriuretic activity. However, this amount of sodium in the diet is normal for a $20-\mathrm{kg}$ dog and for a $60-\mathrm{kg}$ man and, on a body weight basis, GFR in dog is more than twice that of human. Thus, $F E_{N a}$ is about equal in the two species on the same sodium intake. Our failure to demonstrate natriuretic activity in biological fluids collected from sheep and rats (unpublished observation), dogs (present experiments), or man (3-6) on a normal salt intake presumably relates to the relative insensitivity of the bioassays used to test for humoral natriuretic substances. In the same context we are aware of no report describing natriuretic activity in blood or urine from normal animals or man tested while on a normal sodium intake in the absence of other superimposed experimental conditions.

The relationship between the 4-day cumulative sodium balance and the changes in mean $\mathrm{FE}_{\mathrm{Na}}$ in the rat

TABLE V

Effects of the Urine Fraction on GFR and Sodium Excretion in the Rat

\begin{tabular}{|c|c|c|c|c|c|c|}
\hline \multirow{2}{*}{$\begin{array}{c}\text { Dog } \\
\text { no. }\end{array}$} & \multicolumn{3}{|c|}{ Control periods } & \multicolumn{3}{|c|}{ Experimental periods } \\
\hline & GFR & $\mathrm{U}_{\mathrm{Na}} \mathrm{V}$ & $\mathrm{FE}_{\mathrm{Na}}$ & $\Delta \mathrm{GFR}$ & $\Delta \mathrm{U}_{\mathrm{Na}} \mathrm{V}$ & $\Delta \mathrm{FE}_{\mathrm{Na}}$ \\
\hline \multicolumn{7}{|c|}{ Group A } \\
\hline 8 & 0.71 & 4.13 & 4.42 & -0.05 & -0.02 & +0.62 \\
\hline 9 & 0.52 & 4.77 & 6.88 & +0.05 & +0.12 & -0.36 \\
\hline 10 & 0.30 & 1.51 & 3.96 & -0.05 & +0.37 & +1.26 \\
\hline 11 & 0.68 & 2.72 . & 3.24 & -0.09 & +0.59 & +1.29 \\
\hline Mean & 0.55 & 3.28 & 4.62 & -0.04 & +0.26 & +0.70 \\
\hline $\pm S E$ & 0.09 & 0.72 & 0.78 & 0.03 & 0.13 & 0.38 \\
\hline$P$ & & & & NS & NS & \\
\hline \multicolumn{7}{|c|}{ Group B } \\
\hline 1 & 0.40 & 2.43 & 5.75 & 0 & +0.53 & -0.01 \\
\hline 2 & 0.84 & 4.00 & 3.35 & -0.03 & +1.99 & +1.87 \\
\hline 3 & 1.68 & 5.06 & 11.15 & -0.06 & +0.37 & +0.36 \\
\hline 6 & 0.34 & 2.20 & 4.72 & +0.04 & 0 & -0.50 \\
\hline 8 & 0.06 & 1.91 & 20.49 & 0 & +0.37 & +2.98 \\
\hline 9 & 0.33 & 4.72 & 10.47 & -0.03 & -0.21 & +0.42 \\
\hline 10 & 0.73 & 3.66 & 3.70 & -0.01 & +0.85 & +0.93 \\
\hline Mean & 0.62 & 3.42 & 8.51 & 0 & +0.55 & +0.86 \\
\hline$\pm \mathrm{SE}$ & 0.20 & 0.47 & 2.32 & 0.01 & 0.27 & 0.45 \\
\hline$P$ & & & & NS & NS & NS \\
\hline \multicolumn{7}{|c|}{ Group C } \\
\hline 1 & 0.98 & 10.32 & 8.28 & -0.12 & -1.22 & +0.64 \\
\hline 2 & 0.77 & 7.70 & 18.80 & -0.15 & -1.98 & +0.09 \\
\hline 3 & 0.74 & 2.70 & 2.91 & +0.02 & +1.58 & +1.26 \\
\hline 4 & 0.18 & 0.98 & 4.32 & -0.01 & -0.03 & -0.28 \\
\hline 6 & 0.47 & 4.14 & 6.41 & 0 & +0.54 & +0.83 \\
\hline 7 & 0.62 & 2.46 & 2.97 & +0.12 & -0.11 & -0.59 \\
\hline 8 & 0.39 & 1.48 & 2.89 & -0.02 & +0.50 & +1.08 \\
\hline 9 & 0.92 & 4.69 & 3.82 & -0.08 & -0.40 & +0.05 \\
\hline 10 & 0.13 & 0.95 & 5.48 & -0.01 & +0.10 & +1.24 \\
\hline Mean & 0.57 & 3.96 & 6.20 & -0.08 & -0.11 & +0.48 \\
\hline$\pm \mathrm{SE}$ & 0.10 & 1.07 & 1.68 & 0.02 & 0.34 & 0.22 \\
\hline$P$ & & & & NS & NS & NS \\
\hline
\end{tabular}


TABLE V-(Continued)

\begin{tabular}{|c|c|c|c|c|c|c|}
\hline \multirow{2}{*}{$\begin{array}{l}\text { Dog } \\
\text { no. }\end{array}$} & \multicolumn{3}{|c|}{ Control periods } & \multicolumn{3}{|c|}{ Experimental periods } \\
\hline & GFR & $\mathrm{UN}_{\mathrm{Na}} \mathrm{V}$ & $\mathrm{FE}_{\mathrm{Na}}$ & $\Delta \mathrm{GFR}$ & $\Delta \mathrm{U}_{\mathrm{Na}} \mathrm{V}$ & $\Delta \mathrm{FE}_{\mathrm{Na}}$ \\
\hline \multicolumn{7}{|c|}{ Group D } \\
\hline 8 & 0.93 & 4.51 & 3.75 & +0.09 & +2.12 & +1.27 \\
\hline 9 & 0.60 & 1.19 & 1.50 & +0.02 & +1.12 & +1.30 \\
\hline 10 & 0.83 & 4.02 & 3.85 & -0.03 & +0.40 & +0.61 \\
\hline 11 & 0.80 & 5.03 & 4.91 & -0.02 & +0.70 & +0.81 \\
\hline 12 & 0.44 & 3.31 & 5.52 & +0.04 & +1.91 & +2.43 \\
\hline 13 & 0.90 & 2.49 & 2.17 & +0.03 & +0.56 & +0.14 \\
\hline 14 & 1.02 & 4.34 & 3.26 & -0.11 & +2.43 & +2.48 \\
\hline Mean & 0.78 & 3.55 & 3.56 & 0 & +1.32 & +1.29 \\
\hline $\pm S E$ & 0.07 & 0.50 & 0.53 & 0.02 & 0.31 & 0.34 \\
\hline$P$ & & & & NS & $<0.01$ & $<0.02$ \\
\hline \multicolumn{7}{|c|}{ Group E } \\
\hline 1 & 0.48 & 5.02 & 7.34 & -0.05 & +2.38 & +8.04 \\
\hline 2 & 0.39 & 2.31 & 4.19 & +0.03 & +1.80 & +2.75 \\
\hline 3 & 0.30 & 2.11 & 5.06 & -0.02 & +2.60 & +5.60 \\
\hline 4 & 0.60 & 4.89 & 6.10 & -0.04 & +1.35 & +2.21 \\
\hline 5 & 0.46 & 3.32 & 5.33 & +0.13 & +1.54 & +0.77 \\
\hline 8 & 0.47 & 2.17 & 3.40 & 0 & +1.17 & +1.82 \\
\hline 9 & 0.76 & 7.52 & 7.52 & -0.15 & +1.84 & +4.42 \\
\hline 10 & 0.53 & 4.73 & 6.80 & -0.10 & +0.60 & +2.88 \\
\hline Mean & 0.49 & 4.00 & 5.71 & -0.02 & +1.66 & +3.56 \\
\hline$\pm \mathrm{SE}$ & 0.04 & 0.66 & 0.52 & 0.03 & 0.22 & 0.53 \\
\hline$P$ & & & & NS & $<0.001$ & $<0.005$ \\
\hline
\end{tabular}

The mean values for $\mathrm{GFR}, \mathrm{U}_{\mathrm{Na}} \mathrm{V}$, and $\mathrm{FE}_{\mathrm{Na}}$ for the clearance periods obtained over the 60 -min interval after infusion of the fraction were compared with the mean values obtained during the last two control clearance periods. The values under "experimental periods" thus represent the differences in GFR, $\mathrm{U}_{\mathrm{Na}} \mathrm{V}$, and $\mathrm{FE}_{\mathrm{Na}}$ between the mean experimental and the mean control periods. Groups of dogs are defined in Table I.

or SCC in the toad bladder is depicted in Fig. 4. With both assays a highly significant correlation was demonstrated $(P<0.005)$. Fig. 4 also suggests that a cumulative positive sodium balance of approximately $150 \mathrm{meq}$ is necessary for consistently positive results with both the toad bladder and the rat assays. In animals with an average body weight of $20 \mathrm{~kg}$, this degree of sodium retention would be associated with an expansion of extracellular fluid volume of approximately $20 \%$.

Although the identical nature of the inhibitors of sodium transport in uremia and in normal volume-expanded dogs can only be established with certainty by isolating the respective substances, common biologic properties and physicochemical characteristics suggest that a single inhibitor may be operative. When the same gel filtration system is used for fractionation of the urine samples, both active fractions have the same elu-

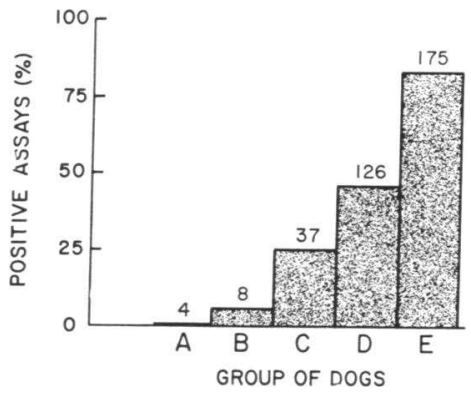

FIGURE 3 Incidence of positive assays observed in the isolated toad bladder and in the rat bioassay systems with the urine fraction from each group of dogs. A positive assay was defined by an inhibition of SCC in the toad bladder of at least $20 \%$ or by a mean increase in $\mathrm{U}_{\mathrm{Na}} \mathrm{V}$ and $\mathrm{FE}_{\mathrm{Na}}$ in the rat of $1 \mu \mathrm{eq}$ and $1 \%$, respectively. The numbers above each bar indicate the mean sodium excretion rates, in $\mu \mathrm{eq} / \mathrm{min}$, present in each group of dogs at the time of urine collection. 

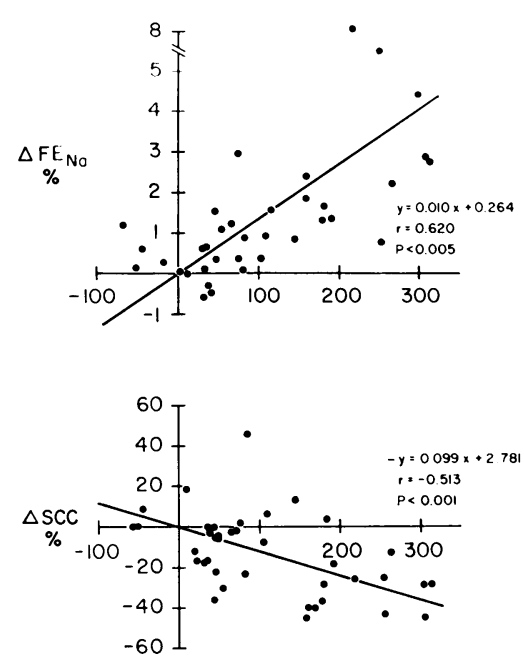

Na intake $-U_{\mathrm{Na}} V$ (meq / 4 days)

Figure 4 Relationship between the 4-day cumulative sodium balance in the dogs (sodium intake- $U_{\mathrm{Na}} \mathrm{V}$, milliequivalents/4 days) and the changes in mean $\mathrm{FE}_{\mathrm{Na}}$ in the assay rats (upper panel) or SCC in the toad bladder (lower panel) induced by the urine fraction from individual dogs. The data for SCC are expressed as a percent change from control values.

tion characteristics appearing after the major peaks of sodium, potassium, urea, and creatinine. Both inhibit SCC and PD across the urinary bladder of the toad, and the patterns of inhibition are indistinguishable. Both are active only when added to the serosal surface of the toad bladder, and neither affects transcellular sodium transport when added to the mucosal surface. Neither produces irreversible effects in the toad bladder, and when the active fraction is replaced by fresh Ringer's solution, both SCC and PD return towards their control levels. Both induce a natriuresis in the rat of comparable magnitude when the same quantity of urine fraction is used. Finally, and most critically, the presence of the inhibitor in the urine of patients and dogs with chronic uremia and of the present dogs with normal renal function appears to correlate with the dictates of maintaining external sodium balance.

A number of other investigators have now demonstrated the presence of natriuretic factor(s) or inhibitor $(s)$ of sodium transport in the blood of animals and man using whole animal experiments (13-21) or in vitro assays $(13,18,20,22-29)$. Similarly, extracts of urine have also been shown to contain natriuretic substance (s) $(16,17,19,20,30-36)$ or inhibitor(s) of sodium transport $(20,37,38)$. Because of different preparative procedures, variations in or different bioassay techniques, and different experimental conditions, the relationship of our findings described in the present ex- periments to the observations of others remains speculative and must await further investigation.

\section{ACKNOWLEDGMENTS}

The authors are grateful to Pat Kanakos and Elvira Pudano for secretarial assistance.

These studies were supported by grants 5 PO1-AM16281, 5 T01-HL05928 from the National Institutes of Health and by grant 74923 from the American Heart Association.

\section{REFERENCES}

1. Levinsky, N. G. 1974. Natriuretic hormones. $A d v . M e-$ tab. Disord. 7 : 37-71.

2. Bricker, N. S. 1967. The control of sodium excretion with normal and reduced nephron population. The preeminence of third factor. Am. J. Med. 43: 313-321.

3. Bourgoignie, J. J., S. Klahr, and N. S. Bricker. 1971 Inhibition of transepithelial sodium transport in the frog skin by a low molecular weight fraction of uremic serum. J. Clin. Invest. 50: 303-311.

4. Bourgoignie, J. J., K. H. Hwang, C. Espinel, S. Klahr, and N. S. Bricker. 1972. A natriuretic factor in the serum of patients with chronic uremia. J. Clin. Invest. 51: 1514-1527.

5. Bourgoignie, J. J., K. H. Hwang, E. Ipakchi, and N. S. Bricker. 1974. The presence of a natriuretic factor in urine of patients with chronic uremia. The absence of the factor in nephrotic uremic patients. J. Clin. Invest. 53: 1559-1567.

6. Kaplan, M. A., J. J. Bourgoignie, J. Rosecan, and N. S. Bricker. 1974. The effects of the natriuretic factor from uremic urine on sodium transport, water and electrolyte content, and pyruvate oxidation by the isolated toad bladder. J. Clin. Invest. 53: 1568-1577.

7. Schmidt, R. W., J. J. Bourgoignie, and N. S. Bricker. 1974. On the adaptation in sodium excretion in chronic uremia. The effects of "proportional reduction" of sodium intake. J. Clin. Invest. 53: 1736-1741.

8. Ussing, H. H., and K. Zerahn. 1951. Active transport of sodium as the source of electric current in the shortcircuited isolated frog skin. Acta Physiol. Scand. 23: 110-127.

9. Guggenheim, S. J., J. J. Bourgoignie, and S. Klahr. 1971. Inhibition by ammonium of sodium transport across isolated toad bladder. Am. J. Physiol. 220: 16511659.

10. Conway, E. J. 1950. Ammonia. Biologic determinations. In Microdiffusion Analysis and Volumetric Error. Crosby Lockwood and Son Ltd., London. 3rd edition. 108-123.

11. Bonsnes, R. W., and H. H. Taussky. 1945. On the colorimetric determination of creatinine by the Jaffe reaction. J. Biol. Chem. 158: 581-591.

12. Fryer, H. C. 1966. Concepts and Methods of Experimental Statistics. Allyn \& Bacon, Inc., Boston. 260.

13. Cort, J. H., T. Douša, V. Pliška, B. Lichardus. J. Safářová, M. Vranešić, and J. Rudinger. 1968. Saluretic activity of blood during carotid occlusion in the cat. Am. J. Physiol. 215: 921-927.

14. Lichardus, B., V. Pliška, V. Uhrín, and T. Barth. 1968. The cow as a model for investigating natriuretic activity. Lancet. 1: 127.

15. Sedláková, E., B. Lichardus, and J. H. Cort. 1969. Plasma saluretic activity: its nature and relation to 
oxytocin analogs. Science (Wash. D. C.). 164: 580582.

16. Sealey, J. E., J. D. Kirschman, and J. H. Laragh. 1969. Natriuretic activity in plasma and urine of salt-loaded man and sheep. J. Clin. Invest. 48: 2210-2224.

17. Sealey, J. E., and J. H. Laragh. 1971. Further studies of a natriuretic substance occurring in human urine and plasma. Circ. Res. Suppl. II. 28: 32.

18. Buckalew, V. M., Jr., and D. B. Nelson. 1974. Natriuretic and sodium transport inhibitory activity in plasma of volume-expanded dogs. Kidney Int. 5: 12-22.

19. Godon, J. P. 1973. Rôle des facteurs physiques et natriurétiques dans la pathologie des oedèmes de la glomérulonéphrite. J. Urol. Nephrol. 80: 412-417.

20. Kramer, H. J., B. Gospodinov, and F. Krück. 1974. Humorale Hemmung des epithelialen Natrium-Transports nach akuter Expansion des Extracellularvolumens. Weitere Untersuchungen zur Existenz eines natriuretischen Hormons. Klin. Wochenschr. 52 : 801-808.

21. Pearce, J. W., and A. T. Veress. 1974. Concentration and bioassay of a natriuretic activity in the blood of volume expanded rats. Physiologist. 17: 304. (Abstr.)

22. Cort, J. H., V. Pliška, and T. Douša. 1968. The chemical nature and tissue source of natriuretic hormone. Lancet. 1: 230-231.

23. Cort, J. H., B. Lichardus, V. Pliška, V. Uhrín, T Barth, and J. Rudinger. 1969. The origin, nature and mechanism of action of natriuretic hormone. In Protein and Polypeptide Hormones. M. Margoulies, editor. Excerpta Medica Foundation, Amsterdam. 523-525.

24. Buckalew, V. M., Jr., F. J. Martinez, and W. E. Green. 1970. The effect of dialysates and ultrafiltrates of plasma of saline-loaded dogs on toad bladder sodium transport. J. Clin. Invest. 49: 926-935.

25. Buckalew, V. M., Jr., and C. D. Lancaster, Jr. 1972. The association of a humoral sodium transport inhibitory activity with renal escape from chronic mineralocorticoid administration in the dog. Clin. Sci. (Oxf.). 42 : $69-78$.

26. Buckalew, V. M., Jr., and C. D. Lancaster, Jr. 1971. Studies of a humoral sodium transport inhibitory activity in normal dogs and dogs with ligation of the inferior vena cava. Circ. Res. Suppl. II. 28: 44-52.

27. Nutbourne, D. M., J. D. Howse, R. W. Schrier, L. B.
Talner, M. G. Ventom, P. J. Verroust, and H. E. de Wardener. 1970. The effect of expanding the blood volume of a dog on the short-circuit current across an isolated frog skin incorporated in the dog's circulation. Clin. Sci (Oxf.). 38: 629-648.

28. Clarkson, E. M., L. B. Talner, and H. E. deWardener. 1970. The effect of plasma from blood volume expanded dogs on sodium, potassium and PAH transport of renal tubule fragments. Clin. Sci. (Oxf.). 38: 617-627.

29. Klahr, S., and H. J. Rodriquez. 1975. Natriuretic hormone. Nephron. In press.

30. Hollowell, J. G., and J. Frazer. 1964. Isolation of sodium transport inhibitor. N. Engl. J. Med. 270: 154155.

31. Kruck, F. 1967. Biologischer Nachweis eines humoralen natriuretischen Prinzips im Urin gesunder Menschen. Klin. Wochenschr. 45: 30-34.

32. Krück, F. 1969. Influence of humoral factors on renal tubular sodium handling. Nephron. 6: 205-216.

33. Kruck, F. 1970. Physiological natriuretic activity in human urine. In Regulation of Body Fluid Volumes of the Kidney. J. H. Cort and B. Lichardus, editors. S. Karger AG., Basel, 100-112.

34. Viskoper, R. J., J. W. Czaczkes, N. Schwartz, and T. D. Ullmann. 1971. Natriuretic activity of a substance isolated from human urine during the excretion of a salt load. Comparison of hypertensive and normotensive subjects. Nephron. 8 : 540-548.

35. Viskoper, R. J., H. Wald, N. Schwartz, and J. W. Czaczkes. 1972. Natriuretic material obtained from urine. Lack of action on renal cortical Na-K-ATPase. Nephron. 9 : 220-224.

36. Godon, J. P. 1975. Sodium and water retention in experimental glomerulonephritis. The urinary natriuretic material. Nephron. 14: 382-389.

37. Clarkson, E. M., and H. E. de Wardener. 1972. Inhibition of sodium and potassium transport in separate renal tubule fragments incubated in extracts of urine obtained from salt-loaded individuals. Clin. Sci. (Oxf.). 42: 607-617.

38. Brown, P. R., K. G. Koutsaimanis, and H. E. de Wardener. 1972. Effect of urinary extracts from saltloaded man on urinary sodium excretion by the rat. Kidney Int. 2 : 1-5. 